\title{
CHARACTERIZATION OF RABBIT MEAT PRODUCTIVITY IN APPLYING
} MINERAL ADDITIVE

\author{
SERGEY YU. SMOLENTSEV ${ }^{1}$, IRINA I. STRELNIKOVA ${ }^{2}$, NATALIA A. SHKAEVA ${ }^{3}$, GIYOSIDDIN \\ ABDIKAKHKHOROV ${ }^{4}$, TATIANA D. ABDYRAMANOVA ${ }^{5}$, VALENTINA P. KOROSTELEVA ${ }^{6}$, \\ VSEVOLODYA. PONOMAREV ${ }^{7}$, GALINA O. EZHKOVA ${ }^{8}$, RASHID M. ASLANOV ${ }^{9}$, ILNUR \\ R.KADIKOV ${ }^{10}$, NAILYA N. MISHINA ${ }^{11}$, ANDREY I. SAMSONOV ${ }^{12}$, ALMAZ R. VALIEV ${ }^{13}$ \\ ${ }^{1,2}$ Mari State University, Lenin Square 1, Yoshkar-Ola City, Russia \\ ${ }^{3,4}$ South Ural State University, Lenin Prospect 76, Chelyabinskcity, Russia \\ ${ }^{5}$ South Ural State Agrarian University, Gagarin Street 13, Troitsk City, Russia \\ ${ }^{6}$ Kazan Innovative University Named After V.G. Timiryasov, Moskovskaya Street 42, Kazan City, Russia \\ ${ }^{7,8}$ Kazan National Research Technological University, Karl Marx Street 68, Kazan City, Russia \\ 9, 10,11, 12, 13 Federal Center for Toxicological, Radiation and Biological Safety, Scientific Town-2, Kazan City, Russia
}




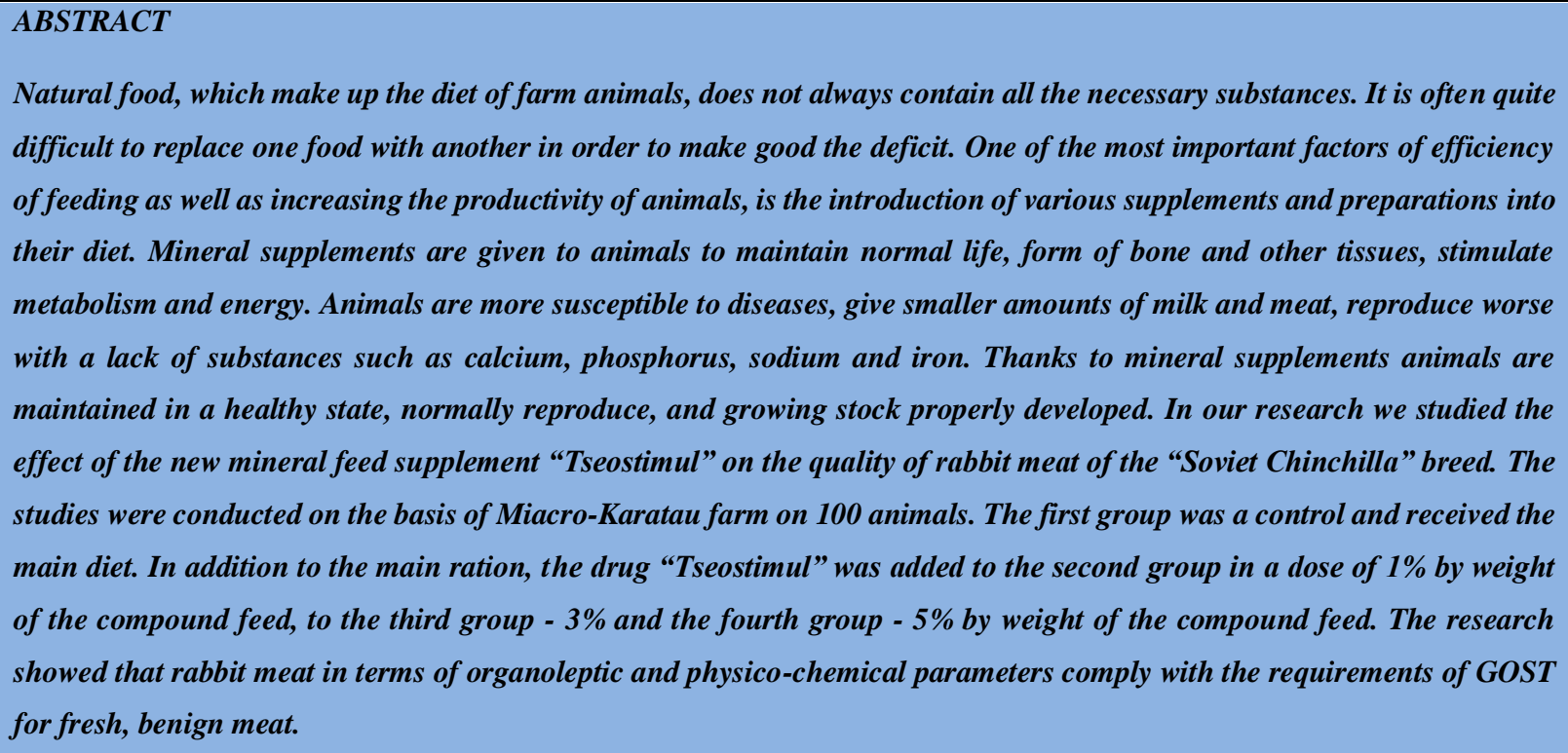

KEYWORDS: Rabbits, Sorbents, Live Weight, Meat Quality, Productivity

Received: Jun 07, 2020; Accepted: Jun 27, 2020; Published: Jul 20, 2020; Paper Id.: IJMPERDJUN2020391

\section{INTRODUCTION}

Today there is a tendency to increase the production of rabbit meat due to its dietary qualities compared to meat of other types of domestic animals. Rabbit meat is highly digestible, contains the least amount of cholesterin and it is fibrillate(Smolentsev et al., 2018).

Today, the use of various feed additives in the diet, which contribute to increasing animal productivity and obtaining environmentally safe and bio-rich products, is becoming relevant in the production of livestock products, including rabbit breeding(Semenov et al., 2018). This is especially important in conditions of environmental pollution with waste from industrial enterprises, which cause the accumulation in feed and feed additives of heavy metals, residues of pesticides, herbicides and other toxicants(Egorovet al., 2018; Galyautdinovaet al., 2020). In this regard, the use of natural sorbents in feeding rabbits is relevant and is of scientific interest(Matveevaet al., 2015;Melniket al., 2020). Due to physical and mechanical properties and chemical composition, these substances have unique ion-exchange and adsorption properties, participate in various metabolic processes and carry out correction of homeostasis of animals, allow to produce environmentally friendly food (Khristoforovich et al., 2016). By the present moment the efficiency of the use of zeolitecontaining rocks and bentonite clays in the diet of cattle, pigs, birds is proved. However, the use of natural adsorbents in rabbit breeding has not been studied enough(Ilyasovich et al., 2016; Valiullin et al., 2017; Popovet al., 2018).

Such additives include "Tseostimul" - a mineral supplement based on sorbents of Hotynetskogo field, the Oryol Region. The combined medication has sorption, molecular sieve, ion-exchange, and catalytic properties.

The purpose of this research is to study the effect of the mineral additive "Tseostimul" on the productivity and quality of rabbit meat.

\section{MATERIALS AND METHODS}


The study was conducted on the basis of the farm "Miakro-Karatau". The object of the study was rabbits of the "Soviet Chinchilla" breed at the age of 50 days. During the experiment, a combined type of feeding with granulated food and hay was used. Animals had unlimited access to water. The rabbits maintenance and feeding was conducted in accordance with the zoohygienic and zootechnical norms.

For research 100 animals were divided into 4 experimental groups of 25 each. The first group was a control and received the main diet, consisting of PZK-90-1feed and mixed herbs hay. The drug "Tseostimul" was added in a dose of 1\% by weight of the compound feed, for the third group - 3\% and the fourth group - 5\% by weight of the compound feed (table) to the main ration of rabbits.

Table 1: Experience Diagram

\begin{tabular}{|l|c|l|}
\hline \multicolumn{1}{|c|}{ Groups } & Number of Heads & \multicolumn{1}{c|}{ Feeding Conditions } \\
\hline 1st control & 25 & Economic Diet (IR) \\
\hline 2nd experimental & 25 & IR + "Tseostimul" (1\% by weight of feed) \\
\hline 3d experimental & 25 & IR + "Tseostimul" (3\% by weight of feed) \\
\hline 4 experimental & 25 & IR + "Tseostimul" (5\% by weight of feed) \\
\hline
\end{tabular}

The experienced rabbits weighing was performed every 10 days in the morning before feeding to study the growth and development dynamics. According to the weighing data, the absolute and average daily live weight gain was calculated.

When the age of 120 days was reached, a control slaughter of 3 heads from each group was carried out to assess the meat quality of rabbits. After the meat aging its organoleptic properties were studied, a commission tasting of meat and broth was carried out.

The quality of the meat was determined in accordance with the requirements of GOST. Protein, fat, water and mineral substance were also determined to assess the quality of meat.

\section{RESULTS AND DISCUSSIONS}

During the experiment, the animals ate well feed, the residues were not observed. At the same time, the studied drug had a positive effect on the growth and development of animals.

Throughout the experiment, the highest live weight values were observed in rabbits of the 3rd experimental group, who received compound feed with the addition of the drug Tseostimul at a concentration of $3 \%$ by weight of the feed. At the beginning of the experiment, the live weight of the rabbits was at the level of 1032.8-1039.4 g. On the 10th day of the experiment the live weight of animals in the control group was 1213.0. The largest live weight was observed in the third experimental group - $1294.0 \mathrm{~g}$. In the second and fourth groups live weight was at the level of $1266.0 \mathrm{~g}$ and $1224.0 \mathrm{~g}$, respectively. On the 30th day of the experiments, animals from the 3rd experimental group had a live weight of an average of $1795.0 \mathrm{~g}$, while animals from the control, 2nd (1\%) and 4th (5\%) groups had live weights in an average of $1597.2 \mathrm{~g}$, $1671.0 \mathrm{~g}$ and $1719.0 \mathrm{~g}$, respectively. At the age of 100 days, rabbits of the $3 \mathrm{rd}$ experimental group weighed an average of $2318.4 \mathrm{~g}$, and control, 2nd and 4th groups - $2119.6 \mathrm{~g}, 2240.6 \mathrm{~g}$ and $2315.8 \mathrm{~g}$, respectively. At the end of the experiment at 120 days of age, the rabbits of the 3rd experimental group also had the largest live weight - $3481.0 \mathrm{~g}$.

At 120 days of age, the animals that received the experimental diet with the test drug had a greater absolute increase in live weight compared with the control group (2169.4 g). The rabbits of the 3rd experimental group had an absolute increase in live weight, it amounted to $2444.4 \mathrm{~g}$ (Tseostimul 3\%), and animals of the 2nd and 4th groups had a result of $2347.4 \mathrm{~g}$ and $2371.6 \mathrm{~g}$, respectively. 
The slaughter mass of the 3rd experimental group rabbits was $12.3 \%$ more than in the control group, in the 2nd and 4 th experimental groups - by $8.7 \%$ and $4.9 \%$, respectively.

The chemical analysis of meat showed that the protein content in the experimental groups increased. The fat content decreased in groups 2 and 4. Compared with the control group, the moisture content increased in the 4th experimental group. When the "Tseostimul" supplement was added to the ration, the calcium content in all experimental groups increased, and there were no statistically significant changes in the phosphorus content among the experimental groups.

The organoleptic assessment showed that the studied rabbit carcasses corresponded requirements of standards. The crust of drying on the carcass surface had a pale pink color. The serous membranes were moist and shiny, the muscles on the incision were slightly moist. The integumentary and internal fatty tissues were yellowish-white. The muscles had a dense, elastic consistency. The smell is specific, peculiar to fresh meat. Consequently, the inclusion in the rabbits diet "Tseostimul" did not have any negative influence on organoleptic characteristics of meat.

The tasting commission in evaluating the meat and broth of the studied rabbits carcass did not reveal the negative effect of the studied drug on the organoleptic properties. At the same time, appearance, color, smell, taste, richness, juiciness were evaluated. On a 5-point scale, meat in the control group received an average of 4.2 points, and samples of meat from the 2 nd, 3rd and 4th groups received 4.0; 4.5 and 4.2 points respectively. The 3rd experimental group also received the highest average score in broth (4.5 points), which is on average 1.3 points more than in the control group.

\section{CONCLUSIONS}

The inclusion of the studied supplements in the rabbits diet did not have a negative impact on the safety and physiological state of rabbits. Rabbits of the experimental groups had the best indicators of weight gain compared with the animals of the control group. The absolute increase in live weight at the end of the experiment was more than the benchmarks by $8.2-12.7 \%$. Organoleptic characteristics of carcasses obtained from experimental animals complied with the requirements of GOST. The tasting evaluation showed that the study drug did not adversely affect the organoleptic properties of meat and broth.

\section{REFERENCES}

1. Egorov, V.I., Valiullin, L.R., Biryulya, V.V., Nabatov, A.A., Smolentsev, S.Y., Papunidi, K.Kh. and Nikitin, A.I. 2018. Toxicity indices of uracil derivatives on lung epithelial cells, Indian Veterinary Journal, 95(6): 33-36.

2. Galyautdinova, G.G., Egorov, V.I., Saifutdinov, A.M., Rakhmetova, E.R., Malanev, A.V., Aleyev, D.V., Smolentsev, S.Yu. and Semenov, E.I. 2020. Detection of tetracycline antibiotics in honey using high-performanceliquid chromatography, International Journal of Research in Pharmaceutical Sciences, 11(1): 313-314.

3. Ilyasovich, S.E., Mikhailovna, T.A., Rasimovich, S.V., Yurievich, S.S., Akhmadullovich, S.F., Khristoforovich, P.K. and Yakovlevich, T.M., 2016. Efficiency of application of a polysaccharide enterosorbent of "Fitosorb" for prevention of the combined mycotoxicoses, Research Journal of Pharmaceutical, Biological and Chemical Sciences, 7(4): 2229-2237.

4. Khristoforovich, P.K., Ravilevich, K.I., Rasimovich, S.V., Yakovlevich, T.M., Mikhailovna, T.A., Akhmadullovich, S.F. and Yurievich, S.S., 2016. Cytomorphological changes hepatorenal system combined with fever poisoning xenobiotics, Research Journal of Pharmaceutical, Biological and Chemical Sciences, 7(4): 2214-2221.

5. Matveeva, E.L., Korosteleva, V.P., Papynidi, E.K., Yusupova, G.R. and Smolentsev, S.Y., 2015. Electron microscopic evaluation of the impact on microorganisms of quaternary ammonium compounds, Research Journal of Pharmaceutical, Biological and 
Chemical Sciences, 6(4): 207-209.

6. Melnik, N.V., Eremets, V.I., Neminuschaya, L.A., Klyukina, V.I., Gryn, S.A., Markova, E.V., Matveeva, I.N. andSmolentsev, S.Yu.2020.Efficiency of probiotics use in treatment of calves, International Journal of Research in Pharmaceutical Sciences, 11(2): 1674-1678.

7. Popov, S.V., Kalyuzhnyi, I.I., Smolentsev, S.Yu., Gataullin, D.H., Stepanov, V.I., Nikitin, A.I. and Zakirova, G.Sh., 2018. Acidbase homeostasis indices upon electric neurostimulation therapy of calves with acute pulmonary pathologies, Research Journal of Pharmaceutical, Biological and Chemical Sciences, 9(3): 553-556.

8. Semenov, E.I., Mishina, N.N., Tanaseva, S.A., Kadikov, I.R., Tremasova, A.M., Papunidi, K.K. and Smolentsev, S.Y., 2018. Systemic anaphylaxis due to combined mycotoxicosis in wister rats, Indian Veterinary Journal, 95(6): 16-19.

9. Smolentsev, S.Yu., Poltaev, E.N., Matrosova, L.E., Matveeva, E.L., Ivanova, A.E., Tremasova, A.M. and Erochondina, M.A., 2018. Stimulation of rumen microflora in cattle by using probiotic concentrate, Research Journal of Pharmaceutical, Biological and Chemical Sciences, 9(2): 948-950.

10. Valiullin, L.R., Idiyatov, I.I., Egorov, V.I., Saitov, V.R., Papunidi, K.K., Raginov, I.S. and Smolentsev, S.Yu., 2017. A study into the safety of novel bioresorbable matrices for repairing bone tissue defects, Bali Medical Journal, 6(2): 88-91.

11. Abid-Ali, Wasfi Dh. "The effect of silymarine extracted from Silibum marianum seeds on histopathological changes in male rabbits liver and kidney induced by nickel chloride toxicity." (2016). IMPACT : International Journal of Research in Applied, Natural and Social Sciences(IMPACT : IJRANSS): 17-22

12. Chakrabarti, Asit, Sc Buragohain, And Kk Baruah. "Digestion Cum Metabolism Trial In Broiler Rabbit Fed On Sweet Potato Based Ration." International Journal Of Applied And Natural Sciences(Ijans) (2017): 111-140

13. Isaac, Okeme, And Florence Obiageli Ifeanyieze. "Entrepreneurial Skill-Support Business In Rabbit Production For Enhancing The Income Of Teachers Of Agriculture In Kogi State, Nigeria." International Journal of Educational Science and Research (2014): 9-18

14. Chakrabarti, A. S. I. T., S. C. Buragohain, and K. K. Baruah. "Carcass characteristics of broiler rabbit fed on sweet potato based ration." International J Agril Sci. and Res. 7 (1): 347358 (2017).

15. Chakrabarti, A. S. I. T., et al. "Effect of sweet potato based ration on physiological and blood profile of broiler rabbit." International J Botany Res. 7(1): $118(2017)$.

16. Abderrahmene, Bouaouiche, And Boulaskoud Mohamed Salah. "Study And Melanocyte Adrenocorticotropic Effects On Sugar Metabolism And Immune Response In Rabbits, Oryctolagus Cuniculus." Best Journals: International Journal Of Humanities, Arts, Medicine And Sciences (Best: Ijhams) $4.10(2017$ 

